\title{
Erratum to: How Ethical Leadership Influence Employees' Innovative Work Behavior: A Perspective of Intrinsic Motivation
}

\author{
Yi Dong Tu $\cdot$ Xin Xin Lu
}

Published online: 28 September 2012

(C) Springer Science+Business Media Dordrecht 2012

Erratum to: J Bus Ethics

DOI 10.1007/s10551-012-1455-7

In the above mentioned article the names of the authors were published in reversed order, that is family name first followed by the given name. This mistake was overlooked by the authors during proofreading.

The author names in the author group should read Yi Dong Tu and Xin Xin Lu, in the affiliation section and on even pages Y.D. Tu and X.X. Lu.

The online version of the original article can be found under doi:10.1007/s10551-012-1455-7.

Y. D. Tu

Economics and Management School, Wuhan University, Wuhan City, Hubei Province, People's Republic of China e-mail: ydtu@whu.edu.cn

\section{X. Lu (ه)}

School of Labor and Human Resources, Renmin University of China, Beijing, People's Republic of China

e-mail: xxlu@whu.edu.cn 